\title{
A CONCEPTUAL FRAMEWORK OF VIRTUAL INTERACTIVE TEACHER TRAINING THROUGH OPEN AND DISTANCE LEARNING FOR THE REMOTE AREAS ENGLISH TEACHERS OF BANGLADESH
}

\author{
Irene PARVIN \\ School of Education \\ Bangladesh Open University, Bangladesh
}

\section{ABSTRACT}

Since we are living in the information age and the importance of the need for communication among people of different cultures is increasing day by day in the globalizing world, people need to learn the languages of different cultures, particularly English, which is the common language of this global communication. This need for learning English requires trained qualified teachers of English. A scan of those who are teaching English in schools of Bangladesh reveals that most of them are very limited in both English skills and teaching methodologies for English. This situation is exacerbated when one moves into the rural areas. Most of the teachers are staying far away from the teachers' training colleges and also for different constraint like administrative, financial, time constraint and were also unable to receive any training due to family problems. So Distance Education has a great demand to them. ICT is an effective media of distance education. For many years, universities with a significant commitment to distance and open education institutions have been at the forefront of adopting new technologies to increase access to education and training opportunities. Information and Communications Technology (ICT) is an umbrella term that includes all technologies for the manipulation and communication of information. Bangladesh Open University (BOU) is till now belonging to the second generation of distance education model but due to the enhancement of technology in Bangladesh, BOU can proceed further. The main purpose of this study is to identify a suitable technology for developing a virtual interactive teachers' training program for the disadvantaged English teachers of Bangladesh. Respondents were selected through random sampling and data were analyzed using both descriptive statistics and quantitative themes. From the opinion of the secondary English teachers their access and acceptability on ICT was identified and also a need analysis was done. It is hoped that the result of this study will encourage the policy makers to implement new ODL approaches for the training of disadvantaged rural English teachers.

Keywords: Open and distance learning (ODL), Bangladesh Open University (bou), virtual interactive teacher training.

\section{INTRODUCTION}

The role of English in Bangladesh is purely a functional one as English is used as an international link language. English is not used as an interpersonal and inter-institutional communication means there but English has been used for years and for different purposes and gradually it is becoming part of the socio-cultural system. Since we are living in the information age and the importance of the need for communication among people of different cultures is increasing day by day in the globalizing world, people need to learn the languages of different cultures, particularly English, which is the common language of this 
global communication. This need for learning English requires trained qualified teachers of English. A scan of those who are teaching English in schools of Bangladesh reveals that most of them are very limited in both English skills and teaching methodologies for English. This situation is exacerbated when one moves into the rural areas but we know secondary education prepares pupils for employment at the entry level and serves as a foundation for those who aspire for advanced studies.

Secondary education of good quality is of utmost developments, which are necessary for successfully tackling the challenges of globalization. In Bangladesh, steady growth in primary education has resulted in concomitant expansion in the number of secondary schools, teachers and enrolments. There are 18,677 secondary schools recognized by the government. About $\mathbf{9 8 \%}$ of them are private schools. There are over $\mathbf{8 . 6}$ million students, of whom about $53 \%$ are girls. The gross enrolment ratio in secondary education averages about 30\% marked by significant losses as grades advance. (ADB Report, 2004)

The total number of teachers is about 240,000 . The current proportion of female teachers is approximately $17 \%$, against the Government's policy of having at least $30 \%$ female teachers. Notwithstanding the quantitative achievements, in the secondary education system weaknesses are reflected in the declining quality of graduates and teachers. About $60 \%$ of the teachers are still untrained, while most schools are devoid of standard conditions essential for the normal instructional process. The decline in the quality of secondary education can largely be attributed to poor teaching. (ADB Report, 2004)

A major issue particularly affecting the disadvantaged population of rural areas is inequitable access and opportunity. Development partners have been working with the Government on a number of projects to alleviate the problems of access, particularly for girls, through stipend programmes. More equitable access to teacher training should also be supported for female students and students from rural areas and disadvantaged groups, including ethnic minorities. Gender and social development policies need strengthening to tackle the inequitable gender balance in hiring and assigning female teachers.

One of the main objectives of the operational strategy of the Asian Development Bank (ADB) in education in Bangladesh is to improve educational quality and system efficiency, particularly in teacher training. ADB assisted the Government to lay the foundations for teacher education in secondary education through several projects, including establishing higher secondary teacher training institutes (HSTTIs), constructing secondary education science development centres (SESDCs), and providing facilities and equipment. ADB's support to Bangladesh Open University (BOU) has on its part also improved teachers' opportunities to further their studies in education. Accordingly, Secondary Education Sector Improvement Project (SESIP) aims to improve secondary education through sector reforms, including the development of policies for teacher education, standards and curriculum (ADB Report: 2004). A number of organizations, including teacher training colleges (TTCs), Madrasah Teacher Training Institute (MTTI), HSTTIs, SESDC, as well as National Academy of educational Management (NAEM), National University (NU) and Bangladesh Open University are involved in providing different aspects of teacher training in secondary education.

Teaching Quality Improvement in Secondary Education Project (TQI-SEP) has four components - improving teaching quality through organizational development and capacity building, improving teacher training facilities, strengthening in-service and pre service teacher training and increasing equitable access and improving community involvement. Implementation will encompass development activities at central Government level, at all teacher training colleges and institutes and on pilot basis at community level. The Continuous Professional Development (CPD) component of the TQI-SEP provides two-week 
face to face subject-based training programmes that require participants to go to one of the government teacher training colleges (TTCs) for the duration of the training. Three Outreached Centres are serving rural and remote areas, are planned in order to be the link between remote schools and training colleges, but they will still require teachers to take leave from their schools to attend training. For many teachers it is difficult to leave their home, family, school and other obligations for an extended period. So, they did a study to explore innovative strategies, including distance learning and the application of ICT to serve educators in remote areas. They tried to examine the use of mobile connectivity in support of distance education because in Bangladesh there is high population density and wide mobile communication coverage. It had been hoped that because all of the participants were experienced phone users and mobile phone owners, they would be able to adapt to and easily integrate the Smartphone.

Most of the teachers are staying far away from the teachers' training colleges and also for different constraint like administrative, financial, time constraint and were also unable to receive any training due to family problems. So Distance Education has a great demand to them but the common problems of distance learners are that they have lack of personal contact and immediate instructor feedback, sense of isolation, lack of pre-course orientation and counselling sessions during course of study (Yousuf, 2006).

Thus, mobile learning can provide helps in various dimensions right from pre-admission counselling, admission, counselling, exams and results. The portability of mobile technology allows the learning environment to be extended beyond the classroom. There are several advantages inherent in mobile learning versus the Internet because it helps to raise selfesteem and self-confidence, cost is pretty affordable, not much technological pre-requisites, portable from one place to another and more wide spread and popular than internet. Mobile learning is more interactive, involves more contact, communication and collaboration with people (Georgieva, 2006).

This study intends to explore the background of remote areas English teachers in order to evaluate their access and acceptability in ICT and other media for developing a framework for virtual interactive teacher training programs.

\section{OBJECTIVES}

The present study is proposed to be undertaken with the following objectives:

$>$ To analyse the access and acceptability of the remote areas English teachers' in ICT and other media and the need of teacher training through distance mode.

$>$ To analyse existing teacher training approaches, curriculum, modules and audiovideo programmes to develop a new approach to train English Language teachers of remote areas.

$>\quad$ To develop an appropriate and accessible model for teacher training using virtual interactive modes in ODL for the development of English teachers.

\section{TOOLS AND METHODOLOGY}

Samples of 819 respondents were selected for data collection consisting of 300 disadvantaged English teachers from 34 remote "Thanas" (Locales) of 15 districts of 6 Divisions. From the Teachers' Training Colleges of 13 districts, data were collected from 87 tutors and 292 students of Bangladesh Open University (BOU) Bachelor of Education (BEd) programme, 115 NGO professionals and 25 BOU teachers. All of the respondents were 
selected randomly. Every attempt was made to ensure female teachers, students and tutors are represented.

Structured questionnaires were prepared for all the respondents. Interviews were conducted with individuals depending on their availability from the sample group.

The data were analyzed using both descriptive statistics and quantitative themes. From the opinion of the secondary English teachers their access and acceptability on ICT was identified and also a need analysis was done. The opinion of the BOU BEd tutors and students helped to identify the strengths and weaknesses of the existing English course of BEd program and also to evaluate their access in ICT. Lastly the opinion of the NGO professionals and BOU teachers along with literature helped the researcher to develop a framework of virtual interactive teacher training for the English teachers of remote areas.

\section{IMPLICATIONS}

It is hoped that the result of this study will encourage the policy makers to implement a new ODL approaches for the training of disadvantaged rural English teachers. It will have implications in the policy of BOU for developing partnership in teacher training with Government (GO) as well as Non-Government Organizations (NGOs). It will provide a valuable insight for all the stakeholders to help the disadvantaged and marginalized English teachers.

\section{Present Status of the Remote Areas English Teachers of Bangladesh}

Data were collected from $\mathbf{3 0 0}$ Secondary English Teachers of rural areas. Fifty nine percent of the respondents had teacher training degree whereas $41 \%$ did not have. Bangladesh Government provided short term training for different subject teachers and $62 \%$ of the respondents received that training. The teachers who did not receive any long or short term training they had some obstacles to receive that. Nearly half $(\mathbf{4 0 \%})$ of the respondents faced administrative problems; (e.g., they were not given leave from their employment, or were excluded from selection because some areas were not using a fair transparent selection process). Furthermore $36 \%$ of the teachers could afford to lose their free time (which was spent providing private classes and tutorials) on training, as this additional money was required for basic livelihood needs. Another $12 \%$ had financial problems, so they could not receive any training and the final $12 \%$ could not participate in due to family constraints; (e.g., they had young children or they were not permitted by their families to attend training. Most $(67 \%)$ of the teachers are residing at a distance greater than 20 kilometres from the teachers' training colleges whereas only $11 \%$ are residing closer than $10 \mathrm{~km}$. In most of the villages the transportation system was not so good and costly, so it is problematic for them to go to the training centres every day from their residence. For all these reasons they felt necessarily of Distance Education which will help them to get training staying at home.

To evaluate the existing BOU TV and radio programme data were collected from them, $85 \%$ of the respondent watches BOU TV programmes but 15\% did not. On the other hand $67 \%$ English teachers were listening BOU radio programme but $33 \%$ did not. Twenty one percent said the TV-radio programmes were poor quality and did not meet their needs and $68 \%$ stated that BOU should improve the quality of its programme. They said it is one way communication, so it creates boredom. To assess their access and acceptability some data were collected, which explored the following results. From the respondents almost all (97\%) of the English school teachers of remote areas did not have access in internet, only a few $(3 \%)$ had access in internet. This $3 \%$ of teachers found to live closest to the Dhaka division and were members of the younger group below $\mathbf{4 0}$ years of age. 
Furthermore $85 \%$ of them have electricity at their school or workplace and $15 \%$ do not have. More than half (67.5\%) of the respondents have access to mobile phone, $52 \%$ in TV, $9 \%$ in radio, $4 \%$ have computer and only $1 \%$ have computer with internet.

BOU students are predominantly rural students with little comfort with technology. However mobile phone is a familiar part of the lives of most teachers and Short Message Service (SMS) is highly cost-effective and very reliable method of communication. Clearly over $\mathbf{5 0 \%}$ of the teachers would have no problems with the mode of delivery, having both access to a mobile phone and a television.

Forty-one percent of the teachers wanted to improve spoken and communicative English, with $16 \%$ only wishing help in spoken English, and only $3 \%$ wanted to develop their Listening, Speaking, Reading and Writing skills. Improvement of teaching was identified by the greatest demand was spoken English a total of 57\%.

Existing Teacher Training Approaches, Curriculum, Modules and Audio-Video Programs To review the existing BEd program data were collected through random sampling from 87 tutors and from 292 BEd students of 13 Teachers' training colleges. All of the BOU BEd tutors have Masters and BEd or MEd degree, because it is obligatory for the tutors of BOU BEd programme to have Masters with BEd or MEd. On the other hand among the sample students of BOU BEd programme, $80 \%$ were teachers and $20 \%$ were non-teachers and $65 \%$ have Bachelor Degree and 35\% have Masters Degree.

About the English course of BEd programme, $41 \%$ tutors said that this course helps the teachers to increase the efficiency in English but nearly half (59\%) thought the existing course does not improve capacity in English. On the other hand 34\% teachers opined that this English course is helpful to make a good English teacher but $66 \%$ thought that it does not help to make a good English teacher. More than half of the respondents did not equate the course with the development of good English teaching skills and really pointed to the need to review outcomes and curriculum. The Tutors provided some suggestions to improve the courses. The majority of the respondents $(52 \%)$ suggested to increase the duration of the English class, providing more tutorial sessions, $26 \%$ suggested to employ trained skilled tutors for teaching English and $22 \%$ suggested the use diversified and effective methods for teaching.

On the other hand, 59\% students stated that the English course of BEd programme is suitable to increase the proficiency in English but $41 \%$ think it does not.Most $(60 \%)$ of the students thought that this English course is suitable to make good English teachers and $40 \%$ thought this course is not helpful to make good English teachers. It is observed that students are more optimistic than tutors. To build up the efficiency in English $(70 \%)$ students suggested providing more practical lessons in English where they will be able to practice the four language skills, $15 \%$ suggested giving emphasis on Grammar and another 15\% suggested to build the foundation of English from elementary class.

Among the respondents only 54\% are watching BOU TV program and only $30 \%$ listen to the radio programs. Ninety percent of the respondents suggested improving the quality of the TV and radio programs. They recommended a more interactive model, because the present situation is just one way communication resulting in boredom. They also suggested changing the broadcasting time from its current morning schedule when people are working to a time when the participants are in their home.

The majority (78\%) of the tutors suggested providing TV and radio programme schedule to the students as well as tutors at the beginning of the semester. 
Access in ICT

Among the remote areas English teachers most (67.5\%) of the respondents have access to mobile phone, $52 \%$ have access in $\mathrm{TV}, 9 \%$ has radio, $4 \%$ has computer and only $1 \%$ has computer with internet.

Furthermore $25 \%$ tutors have access in TV and mobile or cell phone, $20 \%$ have radio, TV and mobile phone, $18 \%$ have TV, mobile phone and computer and rest $14 \%$ have TV, computer with internet and mobile phone at home. From the data of the students, it is observed that $92 \%$ has TV and mobile phone at home, 50\% has radio and mobile phone, 20 has computer, TV and mobile phone, and only $9 \%$ has computer with internet, TV and mobile phone. It reveals a picture that most of them (the students, tutors of BEd programme and also the remote areas secondary English teachers) have access in TV and in a mobile phone.

\section{Acceptability of ICT}

Fifty six percent of the remote areas English teachers think that if BOU offer virtual interactive $T$. programme in which they will be able to interact through mobile that would be helpful for them. There is an overall fascination with Virtual Interactive Teachers' training especially because the majority of them access to be a mobile and TV, in fact these are the only pervasive technologies in rural areas. The table below shows that students of BOU have strong fascination to live TV, radio and in online interactive programs. Students are more positive to new technologies than tutors. Tutors have more interest to live TV programs and less interest to online interaction, they think in Bangladesh there is always power failure and most of the people do not have access in internet, so online interaction will not be feasible.

Table 1. Opinion regarding the usefulness and feasibility of

\begin{tabular}{|c|c|c|}
\hline \multicolumn{3}{|c|}{ ICT for virtual interaction } \\
\hline ICT & BOU BEd tutors & BOU BEd students \\
\hline Usefulness of Live TV programme & $93 \%$ & $84 \%$ \\
\hline Feasibility of Live TV programme & $90 \%$ & $92 \%$ \\
\hline Usefulness of Live radio programme & $67 \%$ & $91 \%$ \\
\hline Feasibility of Live radio programme & $45 \%$ & $91 \%$ \\
\hline $\begin{array}{l}\text { Usefulness of taking class through yahoo } \\
\text { messenger or skype }\end{array}$ & $62 \%$ & $87 \%$ \\
\hline $\begin{array}{l}\text { Feasibility of taking class through yahoo } \\
\text { messenger or skype }\end{array}$ & $23 \%$ & $84 \%$ \\
\hline
\end{tabular}

Framework of the Teacher Training Program for the Remote Areas English Teachers Analyzing the views of the secondary English teachers of rural and remote areas, BOU BEd tutors, students, NGOs and BOU teachers we have come to the conclusion that everybody is feeling necessity of virtual interaction. Especially the secondary English teachers of remote areas have strong fascination for distance education programme which they will be able to do staying at home and not taking leave from the job. Through needs and situation analysis and also summarizing the opinion of the respondents following training structure could be proposed for the remote areas English teachers of Bangladesh.

From each village or Union one tutorial centre could be selected, it could be the coordinating office of BOU or any NGO office that has TV or computer with internet. A fixed time will be given for the students in the weekend and in that time they will come to the tutorial centre. One operator will work there, who will be trained by BOU, no tutor will be needed for those centres. Teachers of BOU and also the tutors of different TTCs will conduct the session. This tutorial session could be offered by TV or through Yahoo messenger and students will participate in the TV program using mobile because most of them have access in it. BOU can negotiate with different mobile company to reduce the charge for BOU students. If the 
tutorial session is taken by Yahoo Messenger or skype, there could be the problem of power failure. To protect it IPS or generator could be used. Most of the teachers of BOU and the tutors of TTCs know how to operate computer, so there will be no problem at all to interact with the students through yahoo messenger or skype.

With the existing BEd course additional English course could be offered to develop the listening, speaking, reading and writing skills of the students. To develop their four skills some video CD could be provided which they will watch after finishing their class in those centres.

Students who have TV or computer at home they will be able to attend the class staying at home but those who don't have they will come to the tutorial centre. From the study it was observed that most of the teachers who are staying in the remote areas, they have access in TV and mobile. Mobile or cell phone has got access everywhere and it is affordable to everyone, even those who are living under poverty line, they can also afford cell phone. So it could be a very good media for virtual interaction. In the study it was observed that most of the developing countries have access in mobile but not in internet.

Exam will be conducted in different schools and colleges and the teachers of those schools or college will work as invigilator. All the four skills should be tested in the exam; otherwise they will ignore the skill which will not be tested.

This structure of training will help many people to be trained at a time and also it will help the remote areas English teachers to build up their efficiency in English and to get quality training.

\section{CONCLUSION AND RECOMMENDATION}

The main purpose of this study is to evaluate the access and acceptability of ICT to the remote areas English teachers, BOU BEd tutors, students, BOU teachers and NGOs to offer an ICT based teacher training program for the disadvantaged English teachers. It was observed that most of them have access in TV and mobile phone, so using those technologies and using the infrastructural facilities of BOU and NGOs, BOU can reach to disadvantaged people to provide them quality training. From the opinion of the existing BEd tutors and students the problems of existing BEd English curriculum, tutorial session and media programs were identified which will help to overcome the shortcomings and to improve the quality of the program to get a better result.

From the ICT policy report it was observe that with 27,000 schools in Bangladesh, teaching eight million students, ICT issues ranging from access, to professional development and infrastructure become magnified. Recognising how the opportunities afforded by ICT within a policy framework can help in this momentous task, Bangladesh intends to use ICT as the key-driving element for socio-economic development. In the ICT policy it was mentioned that a country-wide ICTinfrastructure will be developed to ensure access to information for all, empowering people and enhancing democratic values for sustainable economic development by using the infrastructure for human resources development, governance, e-commerce, banking, public utility services and all sorts of on-line ICT-enabled services. Furthermore, in order to utilize ICT fully, exploiting its immense potential in the economic, social, commercial, and scientific fields a National ICT Task Force headed by the Prime Minister has already been formed (ICT Policy: 2006).

Already mobile has created a good access for most of the people, so it is not far away to have access in computer or internet. So BOU need to take the challenge to offer virtual interactive teacher training program to train the disadvantaged unreached English teachers. Further research could be done to explore the scope and suitability to use cell phone technology in developing countries to make distance learning more interactive and to reach more students who are disadvantaged. 


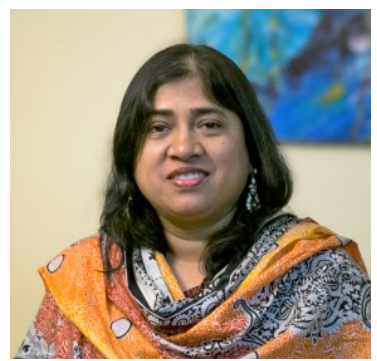

Irene PARVIN currently works in Pathways to Education Canada as a Coordinator of Program Evaluation. She is a former Associate Professor in the Faculty of Education at Bangladesh Open University. She also worked in Dhaka University, Brock University, University of Manitoba, and in George Brown College. She obtained B.A. (Hons) \& M.A. in English Literature and Language from Jahangirnagar University, BEd from Bangladesh Open University, MEd in Educational Research and Evaluation from Dhaka University, Masters in Inclusive Education from Griffith University of Australia and TESL from George Brown College of Canada. She was a Commonwealth scholar. She has 16 Research articles published in Peer-reviewed journals and wrote book chapters for 5 books. Her research interests are Teacher Education, Open and Distance Learning, community development, Inclusive Education, teaching methods and school based assessment.

Irene PARVIN

Coordinator of Program Evaluation

Pathways to Education Canada

439 University Avenue, Suite 1600, Toronto, Ontario M5G 1 Y8

Phone: +1416-646-0123 ext: 209

Email: ireneparvin@gmail.com

\section{REFERENCES}

Aderinoye, R. A., Ojokheta, K.O., \& Olojede, A. A. (2007). Integrating mobile learning into nomadic education programmes in Nigeria: Issues and perspectives. International Review of Research in Open and Distance Learning, 8(2). Retrieved July 8, 2008, from http://www.irrodl.org/index.php/irrodl/article/view/347/919

Ali, M.S., Haque, A.K.E. \& Rumbel, G. (1997). The Bangladesh Open University: mission and promise, Open Learning, 12(2)

Asian Development Bank (2004). Report and Recommendation of the President to the board of Directors on a Proposed Loan to the People's Republic of Bangladesh for the Teaching Quality Improvement in Secondary Education Project. (Unpublished report)

Bates, A.W. (1995). Technology, Open Learning and Distance Education, Routledge, London.

Brown, T.H. (2004). The role of $m$-learning in the future of e-learning in Africa? Retrieved from the online website: http://www.tml.tkk.fi/Opinnot/T-110.556/2004/ Materiaali/brown03.pdf

Daniel, J. (2000). At the End of Now-Global trends and Their Regional Impacts. In V Reddy \& S Maujulika (Ed.), The World of open and Distance Learning. New Delhi, India: Viva Books Pvt. Ltd., 451-461

D'Antoni, S. (2006). The Virtual University models and Messages (Ed.) Lessons from case studies. Retrieved from the online website: http://firgoa.usc.es/drupal/node/26003

Developments.org (2007). Mobile phones help fight poverty in Africa. Retrieved August 8, 2007, from http://www.developments.org.uk/articles/mobile-phones-help-fight-poverty-inafrica/ 
Economics focus: Calling across the divide. (2005). The Economist. Retrieved June 12, 2008, from http://www.london.edu/assets/documents/PDF/The_Economist-

CallingAcrossThe_Divide.pdf

Garrison, R. (1997). Computer conferencing: 'The post-industrial age of distance education', Open Learning, 12, 2.

iConnect Online (2008, September 30). Ericsson to launch mobile Innovation Center in Africa. Retrieved, October 2, 2008. Retrieved from http://www.iconnectonline.org/News/ericsson-to-launch-mobile-innovation-center-in-africa

Kinynanjui, P. E. (1998). Distance Education and Open Learning in Africa: What Works or Does Not Work, Presented at the EDI/World Bank Workshop on Teacher Education through Distance Learning Addis Ababa, Ethiopia.

Naismith, L. et al (2008). Literature Review in Mobile Technologies and Learning. Retrieved from: http://elearning.typepad.com/thelearnedman/mobile_learning/reports/ futurelab_review_11.pdf retrieved on 31.3.2008.

Parvin, I. (2008). Virtual Interactive Classroom: A New Dimension in Distance Education of Bangladesh, Conference Paper.

Pls Ramboll (2004). Studies in the context of the e-learning initiative: Virtual Models of European Universities (Lot 1), executive summary.

Pouezevara, S. and Khan, R. (2007). Learning communities enabled by mobile technology : A case study of school-based, in-service secondary teacher training in rural Bangladesh. RTI International. ADB TA6278-REG. Research Triangle Park.

Rahman, S. (2006). Orientations and Motivation in English Language Learning: a Study of Bangladeshi Students at Undergraduate Level. Asian EFL Journal. Volume: 7(1).

Rumbel, G. (1989). On defining Distance Education, The American Journal of Distance Education. 3(2)

UNESCO (2005). UNESCO Prepares to launch new ICT teacher training project

Wagner, E. D. (2005). Enabling Mobile Learning. EDUCAUSE Review, Vol. 40, no. 3.

Wagner, E. D. \& Robson, R. (2005). "Education Unplugged: Mobile Learning Comes of Age," presentation at the Annual Meeting of the National Learning Infrastructure Initiative, New Orleans, Louisiana, January 24, 2005; Colleen Carmean, blog entry, http://blog.educause.edu/carmean.

Wright, C. R., Dhanarajan, G. \& Reju, S. A. (2009). Recurring Issues Encountered by Distance Educators in Developing and Emerging Nations. The International Review of Research in Open and Distance Learning, Vol 10, No 1 ISSN: 1492-3831

Yousuf, M. (2006). Effectiveness of Mobile Learning in Distance Education. Turkish Online Journal of Distance Education-TOJDE October 2007 ISSN 1302-6488 Volume: 8 Number: 4 Article-9. Retrieved from: http://www.google.co.in/search?hl=en\&q=\%22EFFECTIVENESS+OF+MOBILE+LEARNI NG+IN+DISTANCE+EDUCATION\%22\&meta = 